\title{
Using biogas as an energy source
}

\author{
Alexander Smirnov ${ }^{1}$, Kantemir Tsabolov ${ }^{2}$, Liliya Ineshina $^{2}$, and Elena Gogina, ${ }^{2, *}$ \\ ${ }^{1}$ NII VODGEO, B. Savvinskii per.9, Moscow, 119435, Russia \\ ${ }^{2}$ Moscow State University of Civil Engineering, Yaroslavskoe shosse, 26, Moscow, 129337, Russia
}

\begin{abstract}
This article discusses the topic of sewage sludge digestion. Anaerobic digestion of sewage sludge makes it possible to obtain biogas, which can later be used to generate heat or electricity. this approach to resource use is recognized worldwide as more environmentally friendly. The article discusses the experience of European countries in the production and use of biogas. In the Russian Federation, the situation is complicated by the fact that wastewater contains a small amount of organic matter, which is a product for biogas production. Therefore, methods have been proposed for increasing the content of organic matter in sediments, for example, by means of separate waste collection and disposal of organic waste through grinders into the sewerage system. Or, the amount of organic matter in the sewage sludge can be increased by adding manure from animal farms. The stages of sediment fermentation are considered. The topic of rationality and payback of the use of biogas is raised. Projects already working in different countries are being considered. Possible volumes of gas production and methods of air purification during sludge treatment are considered.
\end{abstract}

\section{Introduction}

In recent years, there has been a worldwide tendency to recycle production waste. This tendency also applies to wastewater treatment. For example, the use of anaerobic fermentation (sludge digester) is gaining popularity both at large wastewater treatment plants and at small ones. This is due to the fact that during anaerobic digestion in structures (sludge digesters) biogas is produced, mainly consisting of methane, which can be a source of heat and energy. This method of obtaining additional energy can largely dispose of unnecessary costs and environmental pollution.

Anaerobic fermentation has long been used in many countries in Europe and in China. For example, Denmark is one of the leaders in the use of biogas in Europe. Biogas accounts for 18 percent of the total energy generated in the country. Germany is the leader in the number of medium and large anaerobic fermentation plants. Already according to 2010 data, there were more than 8 million plants in the country [1].

\footnotetext{
*Corresponding author: goginaes@mgsu.ru
} 


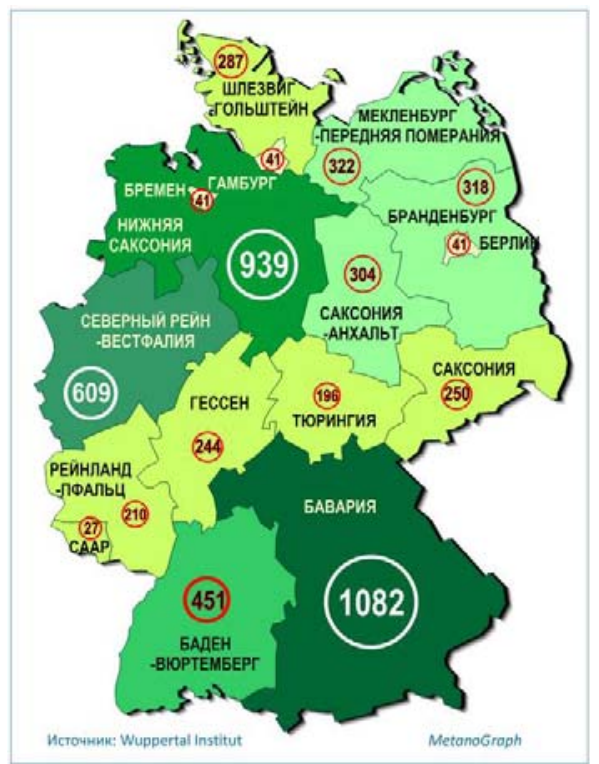

Fig. 1. Technological potential of Germany on obtaining biomethane, $\mathrm{mm}^{3} / \mathrm{yr}$ (for 2006) [2]

There are only about 150 inhabitants in a village located 70 kilometers southwest of Berlin. Throughout the year, 43 wind turbines generate electricity for homes. Windmills are located in the field to be slightly away from the housing. In case of a shortage of wind energy to generate electricity, a biogas plant is used. The raw material for the biogas plant is cow and pig manure, corn and wheat waste. The installation also provides residents with hot water and heating, the total length of the pipes is three kilometers. [2]

Various types of energy are produced using biogas, for example, electricity, heat, steam and automobile fuel. There are also examples of large projects in the United States. $\mathrm{CH}$ Energy Group, Inc. has won a 15-year contract to partially supply the City of Auburn, New York with biogas-generated electricity. [3] In Russia, anaerobic fermentation technologies have been actively used in the last 5 years. For this purpose, sludge digesters and biogas plants are used. The company "BIOS Plus" LLC in 2014 presented its biogas plant, and its creator Vladimir Kononov gave many arguments for the use of animal waste and sewage sludge as a source of biogas and the secondary use of sludge as fertilizers. [4]

The main problem for the implementation of the widespread use of anaerobic fermentation is the cost of such facilities, as well as the duration of the processes. However, M.K. Kaneva carried out estimations of the payback of such projects for farms, as a result of which she proved that the use of biogas fully justifies the funds invested in it. In addition, the energy obtained in this way can significantly reduce the costs of the enterprise and begin to save significant funds in less than two years (depending on the size of the station) [5].

\section{Materials and methods}

However, in order to use anaerobic fermentation, it is necessary to have the basis and conditions for the continuous and justified operation of the facilities. The use of sludge digesters and biogas plants can help communities that lack energy. The use of biogas is more cost-effective than organizing the delivery of fuel from remote locations. In the current conditions, the financial side of the issue is often the most significant, so the question of deriving benefits from the sediment will be more and more relevant every year. So what is 
anaerobic fermentation? Anaerobic fermentation is the decomposition of organic substances by microorganisms without access to oxygen in sealed tanks (sludge digesters).

The digesters are delivered by municipal wastewater, organic waste from various agricultural industries, pig and cattle manure, poultry manure, wastewater from sugarcontaining processing plants, wastewater from distilling plants, etc.

In sludge digesters, the process of biomethanogenesis takes place in four stages:

1. Hydrolysis - transformation of complex polymeric materials using bacteria into simple soluble compounds available to other microorganisms;

2. Acidogenesis - the transformation of sugars and amino acids into hydrogen, carbon dioxide, ammonia and organic acids;

3. Acetogenesis - the transformation of organic acids into ammonia, acetic acid, carbon dioxide and water conduit;

4. Methanogenesis - the transformation of these products into carbon dioxide and methane by methanogenic archaea.

Domestic wastewater from cities and towns of the Russian Federation, as a rule, is quite limited in the amount of organic compounds. In order to obtain biogas for its further use, it is necessary to look for additional ways to increase the organic part of the sediment entering the digester. [5-8]

The use of household disposer is one of the recognized methods for increasing the organic matter content in wastewater and, accordingly, in sludge. [9, 10]

The disposer appeared a little less than a hundred years ago: it was invented by the American architect John Hames in 1927. Soon he patented the device and after a while created the company "InSinkErator", which was engaged in the production of shredders. Today, about half of the US population uses disposers, while in other countries it is slightly less common (for example, in the UK, only six percent of the population has a disposer).

By the way, the Americans liked the device right away, so much so that they tried to grind any waste with it - from the remains of meals to bottle caps and paper. This not only damaged the kitchen appliances themselves, but also led to clogging of the sewers. For this reason, in a number of states, this device was even banned. The company has worked hard to rehabilitate the device and lift the ban. In New York, for example, disposers were legalized again only in 1997.

Research initiated by New York City Mayor Rudolph Giulliani in the mid-1990s showed that household use of a disposer could solve many urban environmental problems. This reduces the amount of food waste, which means there are fewer rats and dogs on the streets, the costs of organizing garbage disposal are reduced, it reduces the carbon footprint, and the issue of landfill gases is resolved. They also considered that the massive use of disposers would increase water consumption and slightly increase electricity consumption. However, this is offset by the benefits received for the city and the reduction in municipal costs (landfills are too expensive "convenience").

Water supply, wastewater treatment and sewerage services remain distrustful of disposers. Disposers assume an additional load on the water treatment system. According to experts of Greenpeace Russia, disposers can solve the problem of organic waste, but the effectiveness of this solution directly depends on the work of the treatment systems. The use of disposers is possible only in cities where digester tanks are installed at the treatment facilities and a system for removing methane and other gases formed in activated sludge is organized. After all, crushed organic waste, getting into the sewer, does not stop emitting gas. The lack of digesters can lead to eutrophication of water bodies, because organic matter provokes the growth of biogenic elements in water bodies.

That is why the growth in the mass use of disposers in the municipal engineering should be accompanied by the modernization of the treatment plant system. [11 - 13] 
It should be noted that along with methane, other gases are formed, such as carbon monoxide (II), carbon monoxide (IV), hydrogen sulfide, small admixtures of hydrogen, nitrogen and ammonia $[14,15]$.

Technological schemes of biogas plants depend on the volume of processing and properties of the material that is fermented, the thermal regime, methods of loading and fermentation of the substrate, and a number of other factors.

The schematic diagram of the anaerobic plant includes a receiving device, a sludge digester (bioreactor), a gasholder and a manure storage.

The products of the biogas plant are gas, solid and liquid fertilizers. At the same time, the content of nutrients in the resulting fertilizer increases in comparison with the usual manure. This fertilizer does not contain helminths, pathogenic bacteria and weed seeds and can be used without traditional aging and storage, and the liquid extract is used directly for irrigation of forage grasses, vegetables, etc. Thanks to the use of fertilizers, it is possible to increase productivity.

In addition, the approximate yield of biogas from the type and the amount of additional raw materials (farm waste) are determined.

The calculation of the biogas output from wastewater is also known.

With a methane content of $45-50 \%$, biogas theoretically demonstrates an energy potential of $5 \mathrm{~kW} \cdot \mathrm{h} / \mathrm{m} 3$.

When using biogas, the following energy output is provided:

- $\quad$ in the form of motor fuels with electricity generation $-34-36 \%$;

- $\quad$ in the form of fuel oil $89-93 \%$;

- in the form of motor fuel with cogeneration (simultaneous production) heat, electricity $-74-88 \%$. [16]

Generation of electricity from biological gas using fuel cells should be recognized as even more promising and economically profitable. In this case, a direct conversion of gas into electricity is provided, which does not require combustion [13].

\section{Discussion}

To calculate the sludge digester at the wastewater treatment plants, it is required to calculate the amount of sludge and its approximate composition to select the mode. Taking into account the specifics of wastewater, the fermentation mode is thermophilic [14], and the concentration of suspended substances in the water supplied the primary sludge tanks is approximately $12 \mathrm{~g} / \mathrm{l}$. The main process parameters have the following data:

Decomposition limits of organic sediment $r_{0}=53 \%$ decomposition limits of silt $r_{\text {silt }}=44 \%$.

$$
\begin{array}{r}
r=\frac{\left(r_{0} \times O+r_{\text {silt }} \times \mathrm{I}_{\text {bez }}\right)}{\mathrm{M}_{\mathrm{bez}}}=\frac{(53 \times 0,003+44 \times 0,204)}{0,207}=44 \\
\mathrm{G}=\frac{r \times n \times F}{100}=\frac{44 \times 0,56 \times 9,1}{100}=0,39 \mathrm{~m}^{3} / \mathrm{kg}
\end{array}
$$

Then the total output of biogas will be:

$$
\mathrm{G}_{\text {tot }}=\mathrm{G} \times \mathrm{M}_{\text {bez }} \times 1000=0,39 \times 0,207 \times 1000=80,73 \mathrm{~m}^{3} / \mathrm{kg}
$$

The biogas produced in sludge digesters can be used as fuel both at the treatment facilities themselves and at enterprises that need an additional source of energy. Thus, there is a significant saving of money on energy, as well as reducing the release of carbon dioxide into 
the atmosphere. In addition, this method of generating energy reduces the length and need for gas pipelines, which usually go from the source to the waste treatment facilities. The payback time of the project largely depends on the size of the treatment plant, the amount of wastewater, their concentration and additional sources of sludge. Depending on all the circumstances, the period for reaching the break-even point is from 1 to 5 years, with the minimum declared service life of the equipment about 15 years.

In the chain of processing sewage sludge and surplus activated sludge (separation, concentration, deliquefaction, surcharge, etc.), as well as the processing of solid waste, a significant amount is generated and released from many points into the environment (directly or from ventilation discharges of premises) foul-smelling substances (hydrogen sulphide, mercaptans, ammonia, etc.) that are not used for targeted processing, but worsen the perception of the area with sewage facilities.

To prevent the release of foul-smelling substances from the most significant sources of their emission (from $1 \mathrm{~kg}$ of foul-smelling substances per day and concentrations from 5-10 $\mathrm{mg}$ of foul-smelling substances per $\mathrm{m}^{3}$ and higher) in the countries of Northern and Central Europe, in the CIS, incl. in the Russian Federation (Moscow, Kazan, Cherepovets, Nizhny Novgorod, etc.) are becoming increasingly prevalent photo sorption-catalytic method, which allows to effectively purify the air of hydrogen sulfide, ammonia, and volatile organic compounds by UV treatment and sorption-catalytic purification of it, without the accumulation of toxicants in the secondary waste.

The features of the photo sorption-catalytic treatment include a constantly high (up to 99\%) efficiency for all target toxicants, low total energy consumption, no costs for prepreparation, including air drying, complete safety with respect to explosive components contained in the air and industrial serial production of complete containerized equipment in Russia, by the Moscow company LIT $[17,18]$.

\section{Conclusion}

The use of sludge digesters and biogas plants is a promising trend in the field of green energy and economy. The transition to sludge treatment schemes using anaerobic fermentation requires large investments, but it is not a loss-making enterprise. In addition, sludge digesters are quite flexible structures, the modernization of which is not an impossible task. Moreover, given the tendency of environmental deterioration in the world, precisely such technologies should come to the fore. One possible method for increasing the fermentation yield of rich gas is to increase the amount of organic matter in the wastewater or to add animal farm manure to the fermentation sludge. This approach allows you to solve several problems at the same time - to obtain biogas and, accordingly, additional energy and to process manure from animal farms.

\section{References}

1. R. G. Shayakhmetov, Investigation of mixing methods in methane tanks, The young scientist, 12 (23), 1 (2010)

2. Villages that live on wind energy are no longer rare in Germany URL: https://ria.ru/20110620/390814830.html

3. U. V. Voronov, S. V. Yakolev Wastewater and wastewater treatment (Moscow: Moscow State University of Civil Engineering), (2006)

4. Biogas in agriculture URL: ttps://www.agroxxi.ru/zhivotnovodstvo/intervyu/biogaz-vselskom-hozjaistve.html 
5. H. Q. Tran, E. S. Gogina, Methods of reconstruction and modification of the sequencing batch reactor at municipal wastewater treatment plants in Vietnam, Vestnik MGSU, 5 (2019)

6. H. Q. Tran, E. S. Gogina, V.T. Quang, The biological treatment of laboratory SBR model with biofilm, MATEC Web Conf. 25103029 (2018)

7. V. V.Lozovetsky, V. V.Lebedev, G. S. Dugin, Ensuring environmental safety of landfills for waste disposal based on biogas utilization systems, Problems of the environment and natural resources, 2 (2011)

8. E.V.Gogol, I. Kh.Mingazetdinov, G. I.Gumerova, O. S.Egorova, S. A.Maltseva, I. G.Grigorieva, Yu. A Tunakova, Analysis of existing methods of recycling and recycling of polymer waste, Bulletin of Kazan. technol. un-ta, 10 (2013)

9. N. A.Chadova,, A. Yu Chadov, Technologies of biogas production and prospects of its application in Russia, Materials of the VIII International student electronic scientific conference "Student Scientific Forum". (2019)

10. Four misconceptions about biogas plants. URL: http://latifundist.com/blog/read/1223-4zabluzhdeniya-o-biogazovyh-ustanovkah.

11. What is a green economy? URL: https://www.greenkaz.org/index.php/informatsiya/zelenaya-economika.

12. http://bioenergycrops.com/blog/2013/02/27/energy-crops-for-biogas/

13. N. V.Obolensky, A.V.Martyanychev, M. S. Vandysheva, Method for obtaining biogas and fertilizers// Karelian Scientific Journal, 1 (10) (2015)

14. V. N.Kuznetsov, V. P. Panov, Problems of automated production of high-percentage biogas yield and sediment stabilization in methane tanks, Bulletin of the South-West State University. Series: Management, computer engineering, Computer science. Medical instrumentation, 1 (2014).

15. Electricity from biogas and the use of biogas technology URL: http://biogazrussia.ru/ehlektroehnergiya-iz-biogaza

16. O. G.Chudakova, D. V. Beskrovny, Analysis and assessment of wastewater from brewing production, Bulletin of the Technological University, 16 (2015)

17. A. K.Strelkov, L. M.Vasilyak, A.D.Smirnov, Removal of odors at municipal enterprises: the experience of various countries, Voda Magazine [electronic resource], 24.07.2020 URL: https://watermagazine.ru/nauchnye-stati2/novye-stati/24162-udalenie-zapakhovnapredpriyatiyakh-kommunal-nogo-khozyajstva-opyt-razlichnykh-stran.html

18. A.M.Ponomarenko, D. Yu.Vlasov, N. S.Basov, S. N.Novikov, N. N.Kudryavtsev, S. V. Kostyuchenko. Engineering aspects of the organization of odour removal at sewage treatment facilities of Mosvodokanal JSC, Water supply and sanitary equipment, 1 (2021). 